\title{
Tufted angioma arising at the site of hepatitis B vaccination: A case report
}

\author{
Mozhdeh Sepaskhah, Jalal Hajizadeh, Fatemeh Sari-Aslani, Farideh Jowkar \\ Molecular Dermatology Research Center, Shiraz University of Medical Sciences, Shiraz, Iran. \\ E-mail: sepaskhah_m@yahoo.com \\ Received: 7th April 2017, Accepted: 19th May 2017
}

\begin{abstract}
SUMMARY: Sepaskhah M, Hajizadeh J, Sari-Aslani F, Jowkar F. Tufted angioma arising at the site of hepatitis B vaccination: A case report. Turk J Pediatr 2018; 60: 188-190.

Tufted angioma is a benign vascular proliferation which presents most commonly in infants and children and could occasionally be complicated by KasabachMerritt syndrome. Here, we report a 4-month-old girl with erythematous firm plaque on left thigh at the site of hepatitis $B$ vaccine injection accompanied with thrombocytopenia. Histological examination showed multiple lobules of capillary sized vascular proliferation in the dermis and subcutaneous fat (cannonball appearance) with dilated thin walled vascular channels at the periphery of the lobules. According to our search this patient is the second case of tufted angioma arising at the site of vaccination.
\end{abstract}

Key words: skin neoplasms, hemangioma, vaccination, infant.

Tufted angioma (TA) is a vascular tumor, described in $1949 .{ }^{1}$ It presents as a tumor or infiltrated plaque which usually appears during the first five years of life; but rarely presents at birth. ${ }^{2,3}$ Kasabach-Merritt phenomenon (KMP) is a microangiopathic hemolysis and coagulopathy as a complication of TA. ${ }^{4}$ Tufted angioma has been reported at the site of BCG vaccination. ${ }^{5}$ We report a 4 -month-old girl presented with tufted angioma at the site of hepatitis $B$ vaccination.

\section{Case Report}

A 4-month-old girl presented to our clinic with erythematous plaque on left thigh at the site of hepatitis B vaccine injection, since about 6 days of age. Midwife did not report this lesion at birth time; also we presume that there had been no lesion at the site before injection because health personnel are expected not to inject the vaccine if there is any abnormality unless they consult a physician. The lesion was a $15 \times 10 \mathrm{~cm}$, erythematous, ill-defined, firm, warm and tender plaque (Fig. 1). The patient's vital signs were normal. Laboratory examination showed white blood cell count $10,000 / \mathrm{mm}^{3}$, red blood cell count $4.53 \times 10^{6} / \mathrm{mm}^{3}$, hemoglobin $9.8 \mathrm{~g} / \mathrm{dl}$ (normal for her age) and platelet count $21,000 / \mathrm{mm}^{3}$. Bone marrow aspiration and flow cytometry were normal. Histological examination showed unremarkable epidermis, multiple lobules of capillary sized vascular proliferation in the dermis and subcutaneous fat (cannonball appearance). There were multiple vascular lobules with dilated thin walled vascular channels at the periphery of one lobule (Fig. 2).

Our case was treated with propranolol (1 mg/ $\mathrm{kg}$ /day) and prednisolone $(1 \mathrm{mg} / \mathrm{kg} /$ day $)$ but she was lost to follow up because her family were illegal immigrants and were not accessible. Thus we cannot evaluate the treatment efficacy. The patient's parent was informed and had given consent for participation. No source of financial assistance exists for this case report.

\section{Discussion}

Tufted angioma is a rare vascular tumor which manifests most often during early infancy or childhood; however, it has also been described in adults. ${ }^{1}$

Although differentiation of tufted angioma and kaposiform hemangioendothelioma is debated and they are recently considered to be identical or at least to be within the spectrum of the 


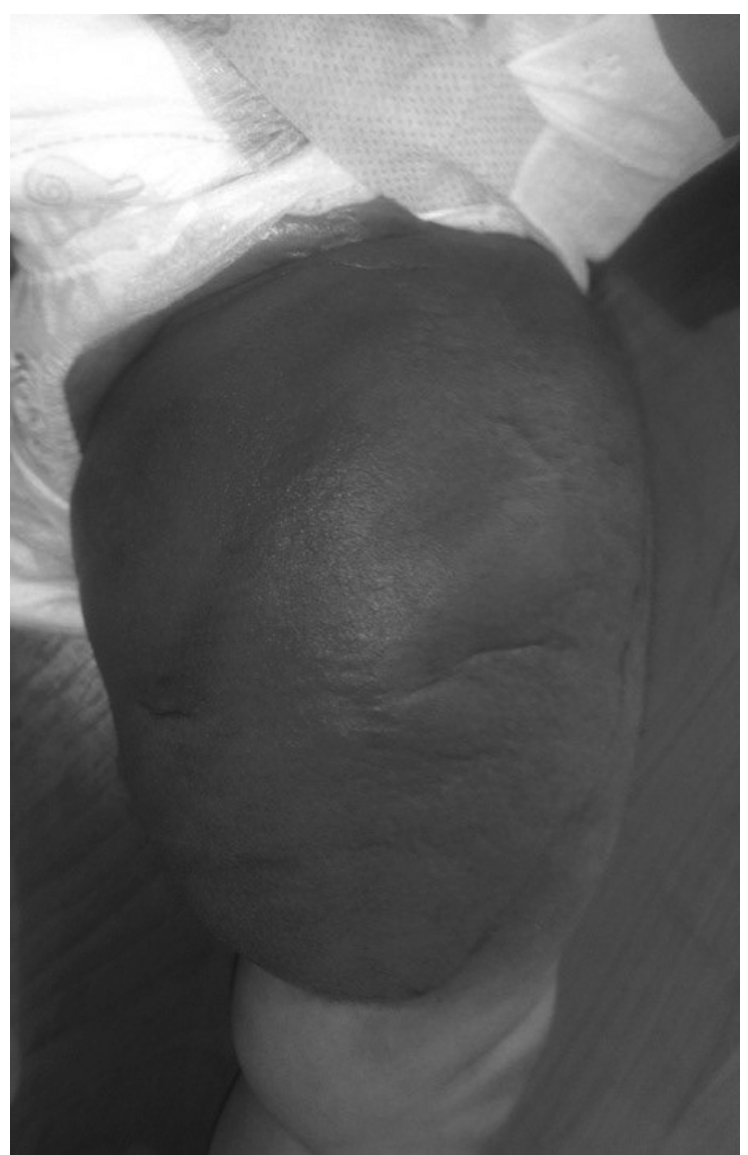

Fig. 1. Erythematous, ill-defined, warm and firm plaque on left thigh at the site of hepatitis $B$ vaccine injection same condition, tufted angioma is characterized by a more superficial location of the tumor and presence of the cannonball-like nests of spindle cells and capillary-sized vessels. ${ }^{6}$ These features were seen in the present case.

Tufted angioma presents as red angiomatous plaques, commonly located on the shoulder, the upper back or the neck. Thirty percent of these plaques are tender, and there may be hyperhidrosis localized to the site of the angioma. Tufted angioma typically undergoes a growth phase of 5 months to 10 years followed by a stabilization phase. The differences between tufted angioma and common infantile hemangioma is persistent dusky color, associated discomfort and continued growth. ${ }^{7}$

Histology of tufted angioma shows the lobular arrangement of densely cellular capillaries (cannonballs) in the dermis. The capillary lobules are present in the dermis and hypodermis; the epidermis is uninvolved in most cases. Rare cases with fascial and muscular involvement are reported. ${ }^{8}$

There is a variety of treatment modalities tried for TA. Cryosurgery, radiation therapy, surgical excision, and electrocoagulation are successful treatments of tufted angioma. Corticosteroids, ticlopidine, propranolol, aspirin and vincristine

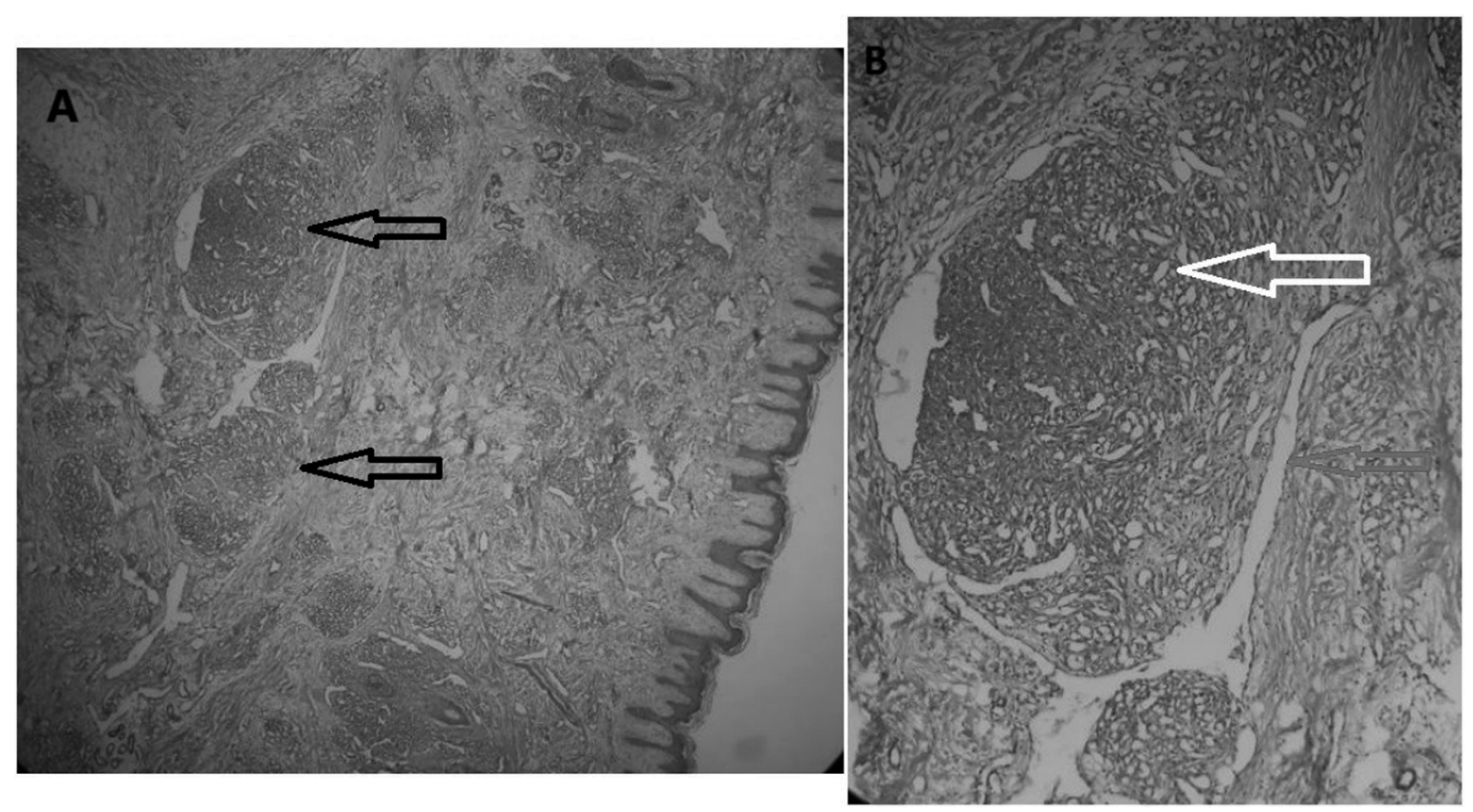

Fig. 2. Histopathological pictures. A. Unremarkable epidermis, multiple lobules of capillary sized vascular proliferation in the dermis and subcutaneous fat (cannonball appearance) (black arrows; $\times 40)$. B. Vascular lobule (white arrow) with dilated thin walled vascular channels at the periphery of the lobule (black arrow) $(\times 400)$ 
are suggested medical treatments. Interferon- $\alpha$ can be used for aggressive lesions. ${ }^{7}$ Pulsed-dye laser treatment is reported for decreasing pain and discomfort and helps to improve cosmesis. ${ }^{9}$

According to our search in PubMed and google scholar only one case of tufted angioma arising at the site of vaccination has been reported and our case is the second one. ${ }^{5}$ However, the type of vaccination is different in two cases. So, possibility of both infectious effect and trauma could be considered as the provoking factors. Anyway, due to paucity of this association an etiologic relationship between vaccination and tufted angioma cannot be claimed and needs further similar cases.

\section{REFERENCES}

1. Osio A, Fraitag S, Hadj-Rabia S, Bodemer C. Clinical spectrum of tufted angiomas in childhood. A report of 13 cases and a review of the literature. Arch Dermatol 2010; 146: 758-763.

2. Browning J, Frieden I, Baselga E, Wagner A, Metry D. Congenital, self-regressing tufted angioma. Arch Dermatol 2006; 142: 749-751.

3. Barco D, Baselga E, Ribé A, Alomar A. Congenital self-limiting tufted angioma. Actas Dermosifiliogr 2008; 99: 423-425.

4. Maguiness S, Guenther L. Kasabach-Merritt syndrome. J Cutan Med Surg 2002; 6: 335-339.

5. Zeng YP, Ma DL. Tufted angioma arising at a site of BCG vaccination. Eur J Dermatol 2013; 23: 102-103.

6. Margolin JF, Soni HM, Pimpalwar S. Medical therapy for pediatric vascular anomalies. Semin Plast Surg 2014; 28: 79-86.

7. Saurez SM, Pensler JM, Paller AS. Response of deep tufted angioma to interferon alfa. J Am Acad Dermatol 1995; 36: 124-126.

8. Jones EW. Dowling oration 1976. Malignant vascular tumours. Clin Exp Dermatol 1976; 1: 287-312.

9. Mahendran R, White SI, Clark AH, Sheehan-Dare RA. Response of childhood tufted angioma to the pulseddye laser. J Am Acad Dermatol 2002; 47: 620-622. 